Kongos de la Guadeloupe: Rites d'une identité préservée. Justin-Daniel Gandoulou. Paris: L'Harmattan, 2011. xi +167 pp. (Paper €18.oo)

In this book Congolese anthropologist Justin-Daniel Gandoulou continues his work on Kongo ethnicity in a diaspora context. He helps to explain the changes and cultural permanence of a group, the Guadeloupe Kongos, who, aside from the 1994 dissertation of Jean-Claude Blanche, are rather forgotten by social history and anthropology research on that island.

Six thousand Kongos were brought to Guadeloupe as indentured laborers after slavery was abolished (1848). The purpose was for planters to make up for the departures of newly freed men from sugar cane plantations and to keep wages low by saturating the labor market with new immigrants (Kongos, East Indians). One and a half centuries later, in a context marked by the dilution of Kongo ethnicity in the Creole melting pot of Guadeloupe and in French culture, an extended family, the Massembos, continues to follow a heterogeneous rite inspired by Kongo ancestors who arrived around 1860 .

It is to that family and to its ritual that Gandoulou dedicates his book. He first focuses on a careful ethnography of the grapp a kongo, a ceremony of tributes to the spirits of the dead that takes place every November 1 . He identifies original Kongo elements as well as the effects of adjustment to the local context: songs in Kongo language (noting that "nowadays, a Congolese Kongo listening to the Massembos singing will not find it particularly difficult to understand those songs" [p. 5o]), with the use of Creole drums, a concession to Guadeloupean Catholicism where All Saints Day merges with the Feast of the Dead.

The book is also a reflection on the transmission of memory. Gandoulou stresses the crucial role of the women in the family, in line with the conventional model where, "due to slavery, the central role of women in the Antillean black family increased" (p. 86). But he stresses the specificity of the Massembos in terms of reproducing the original identity, while most Kongos yielded to the assimilationist pressure by the colonial order and creole blacks. The determined wish to protect the link to the ancestors and to Africa, in spite of unavoidable losses (e.g., the meaning of the Kongo songs is now not understood by those singing them), was due to their exclusion, resulting from the negrophobic, africanophobic environment in 
which they lived. The cost of such tenaciousness was high: marginalization, stigmatization (sometimes within the very Kongo descendents of the island), and identification of the grapp a kongo with sorcery. "It seems it was in the strong belief that they existed for themselves and in the strong idea they had of their own culture that they summoned the necessary resources to continue what some have called 'resistance,' but what I would call counter acculturation" (p. 107).

This resistance was encouraged by the installation of the fourth generation of the family on a "sloping piece of land of about 5000 square meters" (p. 33) in the Cambrefort-Moravie countryside, in Capesterre-Belle-Eau (in the southeast of the island). The departure from the plantation to a place owned by the Massembos was a deciding factor in the durability of the grapp a kongo. The Massembo area, or "Tsibélo tsia ba Massembo" (p. 33), has become the territory of reference for their identity and their ceremonial center. Gandoulou presents a map, a detail of what is now a small family village, including a wooded area, which is sort of a sacred grove. He sees the practice of leaving ten meters between houses as a possible though not certain reminiscence of a Congolese custom that provides space near the household to bury the dead.

In an unforeseen turn of events, the Massembos and their grapp a kongo are now the center of unprecedented attention in Guadeloupe. The progress of decreolization, frenchification, and globalization has resulted in a Guadeloupean quest for internal heterogeneity, which now prompts them to reclaim those things that have survived cultural disappearance. Far from its former ostracism, the Massembo family ritual has become a famous ceremony, supported by Capesterre, with a growing attendance that helps to express a desire for Africa that had long been repressed. The new support is not without risk - the risk, as indicated by Denys Cuche in the preface to the book, "of seeing the ritual become a show intended for an audience increasingly foreign to its source" (p. 12). Already, the Massembos have been asked to take their ceremony to the city stadium for a great African feast. The family resists that threat of folklorization, even if one of its members has sold the sacred songs.

There are multiple benefits to this book. It tells about a group whose identity and history have been little studied and analyzes the case of a group that has resisted pressures for cultural disappearance. Lastly, it identifies 
past and present paradoxical influences that interfere with the preservation of identities.

\section{Gerry L'Étang}

Institut Caribéen d'Études Francophones et Interculturelles

Université des Antilles et de la Guyane

97275 Schœlcher, Martinique

gerry.letang@martinique.univ-ag.fr

\section{Reference}

Blanche, Jean-Claude, 1994. 6 ooo "engagés volontaires" en Afrique et en Guadeloupe (18581861). Ph.D. Dissertation, Université de Paris I. 